\title{
THE OCCURRENCE OF THE VIRUSES IN TULIP CROPS IN POLAND
}

\author{
Dariusz SOCHACKI \\ Research Institute of Horticulture \\ Konstytucji 3 Maja 1/3, 96-100 Skierniewice, Poland \\ Received: January 15, 2013; Accepted: June 17, 2013
}

\begin{abstract}
The viruses infecting tulips have a big influence on the yield and the quality of bulbs and forced flowers. Commercial bulb production is based on clonal propagation, which leads to the accumulation of viruses. Among 22 viruses occurring in tulips, the most common and the most dangerous are Tulip breaking virus, TBV; Tobacco necrosis virus, TNV; Lily symptomless virus, LSV; Cucumber mosaic virus, CMV and Tobacco rattle virus, TRV. The aim of the research was to check which viruses occur most often on Polish tulip plantations. The research was done on two tulip (Tulipa L.) cultivars 'Strong Gold' and 'Leen van der Mark' grown at 3 farms situated in different parts of Poland (Warsaw Region, Pomerania and Podlasie) during 2006-2007, and then at 2 farms located in Warsaw Region during 2008-2011. Five of the most important viruses infecting tulips (TBV, TNV, LSV, CMV, and TRV) were detected by double antibody sandwich enzyme-linked immunosorbent assay (DAS-ELISA) in leaves and in bulbs during the period 2006-2010. In the last year of the research two different strains of TRV were detected (TRV-J and TRV-F) and Tulip virus $X$ (TVX) as well. Search for viruses showed that most often TBV virus was detected both in the leaves and the bulbs regardless of the year and plantations. Yellow flowering cultivar 'Strong Gold' was infected by viruses more often than in bi-coloured (with red) 'Leen van der Mark', because of the difficulties with effective roguing of infected plants due to inconspicuous symptoms of virus infections on yellow coloured flowers. Other viruses were detected sporadically, however increasing occurrence of LSV and TRV was noticed from year to year. In 2011, TVX virus was detected in a few plants of 'Strong Gold' and it was the first case of detection of this virus in tulip in Poland.
\end{abstract}

Key words: Cucumber mosaic virus, DAS-ELISA, Lily symptomless virus, negative selection, Tobacco necrosis virus, Tobacco rattle virus, Tulipa L., Tulip breaking virus, Tulip virus X, virus disease

\section{INTRODUCTION}

The viruses infecting tulips have a big influence on the yield and the quality of bulbs and forced flowers. Commercial bulb production bases on clonal propagation, what leads to the accumulation of viruses. Only negative selection, roguing the suspected plants, control of the vectors transmitting viruses and applying general phytosanitary regime can protect plants from the infections. Among 22 viruses occurring in tulips (Mowat 1995), the most common and the most dangerous are Tulip breaking virus, TBV; Tobacco necrosis virus, TNV; Lily symptomless virus, LSV; Cucumber mosaic virus,
CMV and Tobacco rattle virus, TRV. The best known is TBV described in details by van Slogteren (1971). Since the biggest acreage of tulip crops is in the Netherlands (about 10 thousands ha), most of the information concerning viruses' occurrence comes from this country. From other countries cultivating tulips (Japan, France, USA and New Zealand), data are also published. In Poland, the total acreage devoted to tulip growing, both for bulb production and for cut flowers from the field, is estimated at 1000-1200 ha (Jabłońska 2006). TBV, LSV and CMV are transmitted by aphids, TNV is transmitted by fungus Olpidium brassicae, TRV by nematodes of Trichodorus spp. 
and TVX is transmitted both mechanically and by mites during the bulb storage. The aim of the work was to check what viruses and with what frequency are present on the evaluated plantations, and in a consequence - which vectors are the most important. In Poland, the evaluation of virus infections in tulip crops was not investigated until now. However, some research concerning production of virusfree tulips and virus testing was done (Podwyszyńska et al. 2005; Podwyszyńska and Sochacki 2010; Sochacki and Podwyszyńska 2012).

\section{MATERIALS AND METHODS}

The research was done on two tulip (Tulipa L.) cultivars 'Strong Gold' and 'Leen van der Mark' grown on 3 farms situated in different parts of Poland (A - Warsaw Region, B - Pomerania and C - Podlasie) during the years 2006-2007, and then at 2 farms located in Warsaw Region (farms A and D) during the years 2008-2011.

The leaves for tests were taken before negative selection on the field (randomly from the plants showing the virus diseases symptoms - term I) and after selection (randomly - term II). Bulb scales were taken from harvested bulbs of the same plants that were tested in term II in the years 20062007 or randomly in the years 2008-2011 (term III). For tests, 20 leaf or bulb samples were collected at each date from each cultivar and from each plantation. The samples were tested by double antibody sandwich enzyme-linked immunosorbent assay (DAS-ELISA) (Clark and Adams 1977) using antibodies specific for TBV, TNV, LSV, CMV and TRV. Additionally, in 2011 two DAS-ELISA kits for strains TRV-J and TRV-F as well as for Tulip virus X (TVX) were used.

Kits of $\operatorname{IgG}$ and conjugates for detection of LSV, TBV and TNV originated from the Applied Plant Research - Flower Bulbs and Nursery Stock Sector, Lisse, The Netherlands (later on from the Bulb Quality Support B.V., Lisse, The Netherlands). For detection of TRV kits were from the Loewe Phytodiagnostica, Germany, and for detection of CMV from the Loewe Phytodiagnostica, Germany till the year 2009 and later on the antibodies developed at the Research Institute of Po- mology and Floriculture (now Research Institute of Horticulture) in Skierniewice, Poland, were used (Kamińska et al. 2005). Kits of IgG and conjugates for detecting TRV-J and TRV-F originated from the Bulb Quality Support B.V., Lisse, The Netherlands.

DAS-ELISA tests were performed according to the protocol recommended by the producers, with minor modifications. Leaves and bulbs were ground in phosphate buffered saline (PBS), $\mathrm{pH} 7.4$ and all conjugates were diluted in PBS-T buffer containing $0.1 \%$ Tween 20 (w/v 1:5). Each sample was tested in 2-3 duplicates. The absorbance was measured at $405 \mathrm{~nm}$ using Multiscan II reader (Labsystems, Finland) till year 2009 and since year 2010 using Ledetect 96 reader (Dynamica $\mathrm{GmbH}$, Salzburg, Austria). The samples were considered as infected when the absorbance $\left(\mathrm{A}_{405}\right)$ was at least two times higher than the mean $\mathrm{A}_{405}$ for negative control (according to Clark et al. 1988). In addition, samples with absorbance exceeding the negative control by $50 \%$ to $100 \%$ - usually considered as "suspected" or "plus/minus" - were recorded as infected as well.

\section{RESULTS}

Results obtained during the first two years of the study (2006-2007) on three farms showed, that the most common virus on evaluated Polish tulip plantations is TBV, which was detected very often both in the leaves and the bulbs (Table 1). TBVinfected plants of both evaluated cultivars showed leaf mottle and plants of 'Leen van der Mark' also flower "breaking". More TBV-positive samples were obtained from plantation situated in Warsaw region and more in plants of cultivar 'Strong Gold' than in 'Leen van der Mark', irrespectively of the farm location. TRV hasn't been detected in any sample during the two years of testing. CMV and TNV were detected only twice, first in the bulbs and later in the leaves. LSV was detected more often, totally in 13 samples of 720 tested.

During the next four seasons of indexing, TBV was still the most frequently detected both in the leaves and bulbs (Tables $2 \& 3$ ). Only in a few cases occurrences of TNV (4 samples of 720 
tested), CMV (2 samples of 720 tested) and TRV (4 samples of 720 tested) were detected in the first three years of the experiment (2008-2010). Similarly as in the years 2006-2007, LSV was detected relatively often, totally in 37 samples during four years. In 2011 TRV was detected in both cultivars and on both plantations more often than in previous seasons. One of the two TRV strains tested TRV-F was detected in both cultivars, mainly in the leaves, in total number of 30 samples. In 2011, TVX was detected for the first time in the leaves of 'Strong Gold' plants on both plantations; in four and six positives of 20 samples tested, respectively (Table 3). It was the first report on detection of TVX in tulips in Poland (Sochacki and Komorowska 2012). This virus was not detected in bulbs. Only in some cases, the tested plants were infected with more than one virus. During the whole period of the indexing 42 samples of leaves and 9 samples of bulbs were recorded as infected with two viruses. In addition, five samples of leaves showed mixed infections with three viruses. In most cases, virus complexes were consisted of TBV and LSV or TBV and TRV.

Table 1. Occurrence of Tulip breaking virus (TBV) in tulip crops in Poland determined by DAS-ELISA in the years 2006 and 2007

\begin{tabular}{clrrrrrr}
\hline \multirow{2}{*}{ Farm } & \multirow{2}{*}{ Cultivar } & \multicolumn{5}{c}{ No. of positive samples of 20 tested } \\
\cline { 3 - 7 } & & $\begin{array}{c}\text { Term I - leaves before } \\
\text { selection }\end{array}$ & $\begin{array}{c}\text { Term II - leaves after } \\
\text { selection }\end{array}$ & \multicolumn{2}{c}{$\begin{array}{c}\text { Term III - bulbs in } \\
\text { storage room }\end{array}$} \\
\cline { 3 - 8 } & & 2006 & 2007 & 2006 & 2007 & 2006 & 2007 \\
\hline \multirow{2}{*}{ A } & 'Leen van der Mark' & 18 & 19 & 0 & 2 & 4 & 3 \\
& 'Strong Gold' & 15 & 20 & 3 & 14 & 15 & 13 \\
\hline \multirow{2}{*}{ B } & 'Leen van der Mark' & 2 & 1 & 0 & 0 & 1 & 0 \\
& 'Strong Gold' & 5 & 4 & 3 & 1 & 8 & 6 \\
\hline \multirow{2}{*}{ C } & 'Leen van der Mark' & 2 & 20 & 0 & 0 & 5 & 1 \\
& 'Strong Gold' & 12 & 15 & 2 & 1 & 11 & 4 \\
\hline
\end{tabular}

Table 2. Occurrence of Tulip breaking virus (TBV) in tulip crops in Poland determined by DAS-ELISA in the years 2008-2010

\begin{tabular}{|c|c|c|c|c|c|c|c|c|c|c|}
\hline \multirow{3}{*}{ Farm } & \multirow{3}{*}{ Cultivar } & \multicolumn{9}{|c|}{ No. of positive samples of 20 tested } \\
\hline & & \multicolumn{3}{|c|}{$\begin{array}{c}\text { Term I - leaves before } \\
\text { selection }\end{array}$} & \multicolumn{3}{|c|}{$\begin{array}{c}\text { Term II - leaves after } \\
\text { selection }\end{array}$} & \multicolumn{3}{|c|}{$\begin{array}{l}\text { Term III - bulbs in } \\
\text { storage room }\end{array}$} \\
\hline & & 2008 & 2009 & 2010 & 2008 & 2009 & 2010 & 2008 & 2009 & 2010 \\
\hline \multirow{2}{*}{$A$} & 'Leen van der Mark' & 3 & 19 & 6 & 0 & 0 & 1 & 6 & 3 & 7 \\
\hline & 'Strong Gold' & 18 & 10 & 3 & 10 & 17 & 3 & 19 & 19 & 4 \\
\hline \multirow[b]{2}{*}{$\mathrm{D}$} & 'Leen van der Mark' & 3 & 20 & 4 & 0 & 0 & 0 & 3 & 1 & 10 \\
\hline & 'Strong Gold' & 15 & 20 & 13 & 10 & 9 & 7 & 12 & 14 & 9 \\
\hline
\end{tabular}

\section{DISCUSSION}

The obtained results showed that the most common virus on the four evaluated tulip plantations in Poland is TBV, which is transmitted by aphids in a non-persistent manner. Big number of TBVpositive leaf samples in the first term of testing of both cultivars at almost all farms and during the whole period of the research is not surprising since the samples were collected before the negative selection and roguing and from the symptomatic plants. Results from the second term are more informative concerning health status of the tulip crop. No detection of TBV or detection it in a very few samples was noticed in cultivar 'Leen van der Mark', with exception of farm A in year 2011. In cv. 'Strong Gold' on farms A and D the situation was on the contrary. TBV-positive samples varied from 3 to 17 of 20 tested. 
Table 3. Occurrence of viruses in tulip crops in Poland determined by DAS-ELISA in the year 2011

\begin{tabular}{|c|c|c|c|c|c|c|c|}
\hline \multirow{3}{*}{$\begin{array}{l}\text { Virus } \\
\text { detected }\end{array}$} & \multirow{3}{*}{ Tulip cultivar } & \multicolumn{6}{|c|}{ No. of positive samples of 20 tested } \\
\hline & & \multicolumn{2}{|c|}{$\begin{array}{c}\text { Term I - leaves before } \\
\text { selection }\end{array}$} & \multicolumn{2}{|c|}{$\begin{array}{l}\text { Term II - leaves after } \\
\text { selection }\end{array}$} & \multicolumn{2}{|c|}{$\begin{array}{l}\text { Term III - bulbs in } \\
\text { storage room }\end{array}$} \\
\hline & & Farm A & Farm D & Farm A & Farm D & Farm A & Farm D \\
\hline \multirow{2}{*}{$\mathrm{TBV}$} & 'Leen van der Mark' & 17 & 1 & 6 & 0 & 7 & 2 \\
\hline & 'Strong Gold' & 12 & 15 & 8 & 12 & 3 & 8 \\
\hline \multirow{2}{*}{$\mathrm{TNV}$} & 'Leen van der Mark' & 0 & 1 & 0 & 2 & 0 & 0 \\
\hline & 'Strong Gold' & 0 & 7 & 0 & 0 & 0 & 0 \\
\hline \multirow{2}{*}{ LSV } & 'Leen van der Mark' & 2 & 1 & 0 & 1 & 1 & 0 \\
\hline & 'Strong Gold' & 1 & 0 & 0 & 0 & 0 & 0 \\
\hline \multirow{2}{*}{ CMV } & 'Leen van der Mark' & 0 & 0 & 0 & 0 & 0 & 0 \\
\hline & 'Strong Gold' & 0 & 0 & 0 & 0 & 0 & 0 \\
\hline \multirow{2}{*}{ TRV-J } & 'Leen van der Mark' & 0 & 0 & 0 & 0 & 0 & 0 \\
\hline & 'Strong Gold' & 0 & 0 & 0 & 0 & 0 & 0 \\
\hline \multirow{2}{*}{ TRV-F } & 'Leen van der Mark' & 0 & 0 & 3 & 0 & 5 & 0 \\
\hline & 'Strong Gold' & 6 & 3 & 3 & 10 & 0 & 0 \\
\hline \multirow{2}{*}{ TVX } & 'Leen van der Mark' & 0 & 0 & 0 & 0 & 0 & 0 \\
\hline & 'Strong Gold' & 0 & 4 & 6 & 0 & 0 & 0 \\
\hline
\end{tabular}

The above results show that negative selection done on the plantations was completely effective or highly effective in the case of bi-colour cultivar 'Leen van der Mark'. However, in the case of yellow cultivar 'Strong Gold', on which it is much more difficult to observe visual symptoms of virus infections on the flowers, selection was not effective. Cultivar 'Strong Gold' needs additional negative selections in early spring and after flowering, when the symptoms on the leaves are more visible. Selection during these two periods is not routinely performed in Poland. In the Netherlands this cultivar is included into so called "DASELISA varieties list", which means that obligatory inspection scheme conducted by Flower Bulb Inspection Service includes serological tests (Knippels 2011; Anonymous 2011a). In the $3^{\text {rd }}$ term TBV was detected in many cases in the bulb scales taken from harvested bulbs of the same plants, which were tested in term II in the years 20062007, and were TBV-negative after selection. Similar results showing increase in the detection of TBV in bulbs collected randomly in the years 2008-2011 in comparison to $2^{\text {nd }}$ term were noticed. It seems that plants were infected by TBV during the period from date of selection to date of harvesting the bulbs. It could have resulted from insuffi- cient negative selection after flowering and insufficient chemical protection against aphid vectors of TBV.

Obtained results show that infections with remaining viruses had a lower significance than TBV infections in four evaluated Polish farms. During the whole period of the research, TNV and CMV were detected sporadically. In addition, TRV-positive samples, till the year 2010, were noticed in a very limited number. In the year 2011, when new kit against two strains of TRV ( $\mathrm{J}$ and F) was used, detectability of this virus increased. It can lead to the suggestion that low detectability of TRV in previous years was due to lower sensitivity of detection of TRV-F with the former TRV kit of IgG and conjugate. LSV was detected relatively often, totally in 50 samples of 1680 tested. In the Netherlands, the most common virus in tulips is TBV. However, the average TBV infection in tulip lots detected by DAS-ELISA is low and not exceeds $1.9 \%$ (Knippels 2011). In the case of 'Strong Gold' the average level of TBV detected by ELISA in the year 2011 was $2.6 \%$ (Anonymous 2011b). In this study, almost all lots of samples from Polish farms exceeded the level of TBV virus infection detected in the Netherlands. 
Interesting results are connected with the detection of TVX. In the Netherlands TVX was detected in 1993 in a very limited numbers of lots on a limited number of farms (Knippels 2011). The number of TVX tests is expected to increase in the Netherlands (currently seven thousands per year), firstly because infection rate seems to be increasing, and secondly because an increasing number of countries impose quarantine status on this virus (Beekwilder et al. 2008). The first TVX detection in other countries were reported at the beginning of $21^{\text {st }}$ century: in 2001 in Japan (Yamaji et al. 2001), in 2005 in USA (Tzanetakis et al. 2005), in 2008 in New Zealand (Ward et al. 2008) and in 2009 in Brazil (Rivas et al. 2009). In 2011 TVX was also detected in Poland (Sochacki and Komorowska 2012).

\section{REFERENCES}

Anonymous 2011a. Jaarsverlag Bloembollenkeuringsdienst 2010, Lisse, The Netherlands Anonymous 2011b. ELISA-uitslagen tulp 2011-12. www.bloembollenkeuringsdienst.nl/images/statisti eken/tulp/10_elisa-resultaten\%202010-11.

Beekwilder J., van Houwelingen A., van Beckhoven J., Speksnijder A. 2008. Stable recombinant alpaca antibodies for detection of Tulip virus X. Eur. J. Plant Pathol. 121: 477-485.

Clark M.F., Adams A.N. 1977. Characteristics of the microplate method of enzyme-linked immunosorbent assay for the detection of plant viruses. J. Gen. Virol. 34: 475-483.

Clark M.F., Lister R.M., Bar-Joseph M. 1988. ELISA Techniques. In: Weissbaum A., Weissbaum H., (eds), Methods for Plant Molecular Biology. Academic Press p. 527.

Jabłońska L. 2006. Socio-economic conditions of the Polish floriculture development Zesz. Probl. Post. Nauk Roln. 510, 1: 203-211. [in Polish, with English abstract]

Kamińska M., Śliwa H., Malinowski T. 2005. Partial characterisation of cucumber mosaic virus isolate infecting Lonicera caprifolium L. plants. Acta Sci. Pol., Hortorum Cultus 4(2): 3-10.
Knippels P.J.M. 2011. Recent developments in the inspection schemes of flower bulbs. Acta Hort. 886: 147-151.

Mowat W.P. 1995. Tulip. In: Loebenstein G., Lawson R.H., Brunt A.A., (eds.), Virus and virus-like diseases of bulb and flower crops. John Wiley \& Sons, Chichester, New York, Brisbone, Toronto, Singapore, pp. 352-383.

Podwyszyńska M., Sochacki $\quad$ D. 2010. Micropropagation of tulip: production of virus-free stock plants. In: Jain S.M., Ochatt S.J., (eds.), Protocols for in vitro propagation of Ornamental Plants. Series: Methods in Molecular Biology. Humana Press Inc., USA. 589: 243-256.

Podwyszyńska M., Sochacki D., Kamińska M. 2005. Application of tulip in vitro culture for propagation of virus-free plants. Zesz. Probl. Post. Nauk Roln. 504: 667-674. [in Polish, with English abstract]

Rivas E.B., Galleti S.R., Alexandre M.A.V., Duarte L.M.L., Chagas C.M. 2009. Interception of viruses on foreign tulips in Brazil. Arq. Inst. Biol., Sao Paulo 76, 3: 501-504.

Sochacki D., Komorowska B. 2012. First report of Tulip virus $X$ on tulip in Poland. Plant Disease 96, 4: 594.

Sochacki D., Podwyszyńska M. 2012. Virus eradication in narcissus and tulip by chemotherapy. In: Van Tuyl J., Arens P., (guest eds), Floriculture and Ornamental Biotechnology 6. Special issue Bulbous Ornamentals, Vol. 2. Global Science Book, pp. 114-121.

Ward L.I., Tang J., Quinn B.D., Martin E.J., Clover G.R.G. 2008. First report of Tulip virus $X$ in New Zealand. Plant Pathol. 17: 22.

Tzanetakis I.E., Mackey I.C., Martin R.R. 2005. Tulip virus $X$ (TVX) associated with lemon balm (Melissa officinalis) variegation: first report of TVX in the USA. Plant Pathol. 54: 562.

Van Slogteren D.H.M. 1971. Tulip breaking virus. C.M.I./A.A.B. Descriptions of plant viruses No. 71.

Yamaji Y., Kagiwadu S., Nakabayashi H., Ugaki M., Namba S. 2001. Complete nucleotide sequence of Tulip virus $X$ (TVX-J): the border between species and strains within the genus Potexvirus. Arch. Virol. 146: 2309-2320. 